\title{
CRISE E REPRESENTAÇÃO EMPRESARIAL: O SURGIMENTO DO PENSAMENTO NACIONAL DAS BASES EMPRESARIAIS
}

\author{
Alvaro Bianchi \\ Universidade Metodista de São Paulo
}

\begin{abstract}
RESUMO
O objetivo do trabalho é elucidar as origens da crise da representação empresarial na década de 80 e o surgimento do Pensamento Nacional das Bases Empresariais (PNBE) nesse contexto. Criado em meados de 1987 e institucionalizado em 1990, o PNBE nasceu de uma profunda insatisfação com as respostas à crise que vinham sendo articuladas pela estrutura tradicional de representação do empresariado. Apresentando um projeto que visava a superar o caráter econômico-corporativo das propostas até então colocadas na mesa pelo empresariado, a entidade apresentava uma nova alternativa de caráter hegemônico como saída para a crise. Tal projeto, contudo, nunca assumiu contornos muito definidos. Foi mais uma profissão de fé do que um programa.
\end{abstract}

PALAVRAS-CHAVE: empresariado; representação empresarial; Pensamento Nacional das Bases Empresariais.

\section{INTRODUÇÃO}

O objetivo deste trabalho é discutir as origens da crise de representação do empresariado na década de 1980 e o surgimento, nesse contexto, do Pensamento Nacional das Bases Empresariais (PNBE). É de bom tom, portanto, repassar, mesmo que brevemente, a trajetória dessa representação. As relações existentes entre as classes e entre estas e a forma estatal da classe dominante devem fornecer os materiais sobre os quais a análise se debruçará. Para facilitar o trabalho, serão demarcadas quatro grandes fases, assinalando, assim, de maneira esquemática, os diferentes momentos da ação empresarial, bem como as distintas articulações das classes entre si e entre elas e o Estado.

\section{BREVE HISTÓRICO DA REPRESENTAÇÃO EMPRESARIAL}

A primeira fase compreende o período de 1930 a 1945 e é marcada pela emergência de um processo de industrialização e urbanização no Brasil $^{1}$. Segundo Boris Fausto, a indústria brasileira

\footnotetext{
1 A escolha do marco inicial não é arbitrária. Muito embora o Centro Industrial do Brasil tivesse sido criado em 1904, representando os industriais do Rio de Janeiro, São Paulo, Juiz de Fora e Rio Grande do Sul, é apenas com a formação
}

tinha como características, durante esse período, a dependência do setor agrário exportador, a insignificância da indústria de base, a baixa capitalização e o grau incipiente de concentração (FAUSTO, 1970, p. 19).

À época da Revolução de 1930, a burguesia industrial era um setor social com um peso na economia muito inferior ao setor agro-exportador. Já possuía, entretanto, uma dimensão que lhe possibilitava expressar seus interesses na esfera governamental. A relação de forças objetiva, aquela que se estabelece no nível das forças produtivas e sobre a qual se erguem os grupos sociais, permitia ao empresariado industrial fazer ouvir sua voz ${ }^{2}$. A fundação das federações regionais da indústria no final da década de 1920 e a afirmação de uma

$\overline{\text { de entidades regionais como o Centro das Indústrias de Juiz }}$ de Fora (1926), o Centro das Indústrias de São Paulo (1928) e o Centro das Indústrias Fabris do Rio Grande do Sul (1930) que se consolidará uma estrutura de representação de interesses do empresariado. Por outro lado, a adaptação dessas entidades à legislação varguista deu origem a formas de organização duradouras, que marcarão até os dias de hoje a representação empresarial. Ver, para tanto, Leopoldi (2000), em especial a seção I.

2 Sobre as relações de forças, ver Gramsci (1977, p. 15831586). 
liderança empresarial, cujas figuras mais destacadas eram Roberto Simonsen, em São Paulo, e Euvaldo Lodi e Vicente Galliez, no Rio de Janeiro, são indícios de que, além de ser uma força que objetivamente marcava sua presença na realidade nacional, o empresariado adquiria consciência de seus interesses e procurava organizá-los (LEOPOLDI, 2000, p. 71-81).

A relação entre a burguesia industrial e o Estado não era, entretanto, o idílio descrito pelos autores que viam no Estado pós-1930 o representante dos interesses da burguesia industrial. O governo de Getúlio Vargas foi, inicialmente, aparentemente hostil aos industriais. Chegou até mesmo a investir contra as empresas de capital estrangeiro, criando um imposto de $8 \%$ sobre os lucros remetidos, além de ameaçar taxar lucros, produção e imóveis, elevar as tarifas de importação de matérias-primas e promover uma rígida inspeção sobre instalações e produtos industriais.

A ausência de um projeto desenvolvimentista e a aparente hostilidade para com os empresários nos primeiros anos do governo provisório não impediram, entretanto, que, durante a década de 1930, Vargas tenha atendido várias das reivindicações dos industriais. Mas o atendimento de tais demandas não obedecia, como muitos querem acreditar, a um plano racional de fomento da indústria. Esta se beneficiou, pelo contrário, de um processo espontâneo de substituição de importações motivado pelos altos preços dos produtos importados, devido à desvalorização da moeda, e da inexistência dos recursos necessários para manter o fluxo de compras no exterior (COHN, 1985, p. 297).

Embora seja impossível generalizar a influência do empresariado a partir de alguns exemplos, é possível perceber que existiam, em setores da burguesia industrial, já na década de 1930, projetos que, embora pontuais, demonstravam uma disposição de interferir na definição de políticas governamentais $^{3}$. É necessário ressaltar que são projetos pontuais. Segundo Gabriel Cohn, as reivindicações empresariais durante esse período "se referem de preferência a produtos específicos, exprimem interesses de áreas particulares e não de toda uma classe" (idem, p. 292). Embora para Cohn essas reivindicações não forneçam pistas seguras para localizar a emergência de uma classe

3 Ver a esse respeito Diniz (1978) e Leopoldi (2000). empresarial coesa no Brasil, elas sinalizam a existência de uma consciência econômico-corporativa, importante momento da constituição de uma consciência empresarial propriamente dita. Nesse momento econômico-corporativo, os empresários "sentem a unidade homogênea e o dever de organizá-la, a unidade do grupo profissional, mas não ainda a do grupo social mais amplo" (GRAMSCI, 1977, p. 1 583; tradução do autor).

Um segundo momento da ação empresarial se desenvolverá de 1945 a 1964 e será marcado pela emergência do setor industrial como o mais dinâmico da economia brasileira, muito embora a agricultura ainda fosse o setor predominante, e pela implantação do projeto desenvolvimentista. Esse projeto procurava responder ao esgotamento do processo espontâneo de substituição de importações e às pressões sociais exercidas seja pelo proletariado fabril, seja pelas "classes médias".

O que caracteriza esse projeto desenvolvimentista é a transferência da iniciativa industrializante para o Estado: este passa a "fabricar o fabricante", na conhecida expressão de Gramsci (1975, p. 2018). Essa iniciativa começou a ganhar impulso com a criação da Companhia Siderúrgica Nacional e tomou corpo com a fundação da Petrobrás e do Banco Nacional de Desenvolvimento Econômico (BNDE), em 1953. Foi, entretanto, entre 1955 e 1960 que se deu o salto qualitativo da indústria brasileira e ocorreu uma "intensa expansão e diferenciação industrial, articulada diretamente pelo Estado e pelo seu primeiro plano de ação global: o Plano de Metas do governo Juscelino Kubitschek" (FIORI, 1993, p. 9).

O empresariado participará ativamente da formulação desse projeto através de suas entidades representativas. Na segunda metade dos anos 1940, o empresário Roberto Simonsen criou um Departamento de Economia na Confederação Nacional da Indústria (CNI) e nomeou Rómulo de Almeida seu chefe. A CNI e a Federação das Indústrias do Estado de São Paulo (FIESP), influenciadas por Simonsen, opunham-se ao liberalismo extremado da Confederação Nacional do Comércio e da Associação Comercial de São Paulo e preconizavam um processo de industrialização que não alijava o Estado do processo produtivo, desde que a iniciativa privada tivesse preservado o seu espaço (DINIZ \& BOSCHI, 1987, p. 7; BIELCHOVSKY, 1991, p. 160-163).

O próprio Simonsen participou ativamente dos 
debates que ocorreram no interior do governo Vargas sobre a condução econômica do país. Em 1943, como relator do Conselho de Política Industrial e Comercial, órgão do Ministério do Trabalho, Industria e Comércio, apresentou um relatório no qual suas teses seria desenvolvidas.

As idéias apresentadas por Simonsen no relatório, amparadas nos economistas ligados à CNI, representavam uma opção por um modo de organização da economia baseado, segundo Lourdes Sola, nos seguintes pontos: 1) industrialização acelerada como mola propulsora do crescimento da renda nacional; 2) o mercado interno como motor do desenvolvimento econômico; 3) preocupação com as dimensões sociais do desenvolvimento capitalista, e 4) o Estado como agente do planejamento econômico necessário para o desenvolvimento (SOLA, 1998, p. 70).

Apesar do pleno funcionamento de um Congresso Nacional e de uma estrutura partidária durante esse período, a relação do empresariado com o Estado continuou a ser levada a cabo através do Executivo e dos órgãos de assessoria por ele instituídos. Esse parece ser o caso dos "grupos executivos" criados pelo governo Juscelino Kubitschek com representantes do setor privado e estatal para definir e acompanhar a implementação dos objetivos setoriais do Plano de Metas (FIORI, 1993, p. 9).

É nesse contexto que irão surgir associações industriais paralelas. Aproveitando-se da permissão, contida na Consolidação das Leis do Trabalho, para fundar entidades privadas, os empresários criaram organizações setoriais capazes de articular com maior eficácia, junto ao governo federal, os interesses econômicocorporativos de cada ramo de atividade. Foram fundadas, assim, a Associação da Indústria de Autopeças (1951), a Associação Brasileira da Indústria de Base (1955) e a Associação Brasileira da Indústria Elétrica e Eletrônica (1963), dentre outras (LEOPOLDI, 2000, p. 88-89). Ao mesmo tempo, ocorreu um fortalecimento das entidades do empresariado industrial e uma afirmação da FIESP como a principal representação do setor industrial, suplantando a própria CNI (ibidem).

A participação das associações empresariais nas discussões sobre a política econômica dão conta do novo vigor que elas haviam adquirido. Basta lembrar as divergências de setores do empresariado com o Plano de Metas de Kubitschek e a forte oposição destes ao Plano de Estabilização Monetária de 1958-1959, bem como a realização de uma primeira campanha contra a estatização.

O final desse período foi marcado por um crescimento das mobilizações operárias e populares, pelo fortalecimento dos sindicatos e o surgimento do Comando Geral dos Trabalhadores (CGT), bem como pela radicalização das lutas no campo, com o nascimento e expansão das Ligas Camponesas. A crise pela qual atravessou o país nos primeiros anos da década de 1960 e que iria desembocar na contra-revolução de 1964 acentuou o tom claramente conservador do discurso empresarial, contrapondo-se às demandas do movimento trabalhista.

A contra-revolução de 1964 contou com o apoio decidido do empresariado e inaugurou um terceiro momento na organização e representação de seus interesses. A participação do empresariado na preparação do golpe através do complexo Instituto de Pesquisas e Estudos Sociais/Instituto Brasileiro de Ação Democrática (IPES/IBAD), foi intensa, conforme detalhadamente demonstrado por René Dreifuss (1981).

Pesquisa realizada por Leigh Payne, confirma a extensão do apoio dado pelos empresários. Em uma amostra de 132 industriais paulistas, selecionados devido à sua intensa participação política ente as décadas de 1960 e 1980, Payne registrou que $82,3 \%$ daqueles que haviam iniciado seus negócios antes de 1964 apoiaram o golpe (PAYNE, 1994, p. 25). Rapidamente os empresários colheram os frutos desse apoio. Industriais e banqueiros passaram a ocupar importantes postos governamentais, influindo decisivamente, durante o governo Castello Branco, nas diretrizes econômicas e na reformulação do sistema financeiro.

A idéia, muito difundida, da escassa participação política do empresariado perde muito de sua força com a análise de seu papel nos processos políticos que tiveram lugar nos anos 1960. Tal participação não retirou o papel de protagonista do Estado, é bom que se diga. Este continuou a dirigir o processo de industrialização, seja através do investimento direto, seja através do financiamento à iniciativa privada ou do controle sobre as importações e a política cambial.

Afastado o fantasma da mobilização nas cidades e no campo pela ação repressiva do Estado e reformado o arcabouço institucional, um novo ciclo de desenvolvimento industrial teve lugar. Teve 
início, assim, uma situação na qual ocorreu um aperfeiçoamento do sistema de representação empresarial com a consolidação de uma rede de organizações paralelas à tradicional estrutura corporativa, provocando o fracionamento da representação empresarial (SCHNEIDER, 19971998; WEYLAND, 1998).

Essa estrutura paralela adaptava a representação empresarial à complexa rede de instituições estatais criada pelo regime militar para a definição de diretrizes econômicas. Permitiu, assim, principalmente no período 1964-1974, uma participação direta dos empresários, associados a um corpo técnico, no aparelho estatal. É o caso da constante presença da representação empresarial no Conselho Monetário Nacional (CODATO, 1997). Os interesses representados pelo empresariado, através dessas instituições, mantiveram, ainda, as características anteriores. São interesses parcelares que não superam o patamar econômicocorporativo. Sua participação nessas instituições restringia-se à definição de políticas localizadas relacionadas aos interesses mais imediatos dos setores representados e era realizada sob a iniciativa e o comando do Estado.

A participação direta do empresariado na definição de políticas setoriais não encontrou paralelo na definição das linhas mais gerais da política econômica. A estrutura autoritária montada pelo regime militar afastou as entidades empresariais das esferas mais altas de decisão e, principalmente, do Conselho de Desenvolvimento Econômico, organismo que, a partir de sua criação em 1974, passou a coordenar a política econômica do governo definida pelo II Plano Nacional de Desenvolvimento (idem, p. 234-256).

O fim do "milagre econômico" provocou a emergência de conflitos entre o empresariado e o governo, bem como a reivindicação de maior participação nessas esferas. Desde meados de 1974, a economia brasileira havia entrado em uma fase crítica cujos principais sintomas eram o declínio da taxa de acumulação e a aceleração da inflação. Essa crise, gerada pela incompatibilidade entre as taxas de acumulação e de crescimento da demanda efetiva de bens duráveis de consumo (MELLO \& BELLUZO, 1977), combinou-se com a crise da economia mundial que se processava desde o início da década e que atingiu seu ponto mais dramático durante o chamado "choque do petróleo" em 1974.

A crise econômica colocou o empresariado dos setores que mais haviam se beneficiado do período anterior frente à perspectiva de queda das altas taxas de lucro. "O desequilíbrio entre expectativas e ganhos reais, gerando insatisfação, provocou os primeiros indícios de uma atitude de protesto que, posteriormente, viria a irradiar-se para outros segmentos do meio empresarial" (DINIZ, 1984, p. 19).

A campanha contra a estatização marcou a reação de setores do empresariado ao desgaste do modelo desenvolvimentista sustentado até então pelo regime militar. A campanha criticava o aumento do Estado e os excessos da intervenção estatal, principalmente nos setores de transportes, mineração, comunicações e siderurgia. Além de atacar a centralização da atividade econômica pelo Estado, os empresários questionavam a centralização excessiva de poder e a autonomia decisória que os tecnocratas responsáveis pela definição da política econômica haviam adquirido. Essa demanda política tornar-se-ia a principal preocupação do empresariado ao longo da campanha antiestatização.

A mobilização empresarial não pode, entretanto, ser interpretada como uma reação direta à crise econômica. Velasco e Cruz ressalta que a adoção de um projeto liberalizante até mesmo antecedeu os primeiros sinais da crise (CRUZ, 1995). É preciso perceber que a campanha é um momento no qual os empresários afirmam que não aceitarão mais o papel subalterno ao qual suas entidades haviam sido até então relegadas. A relação entre essa nova atitude e a crise precisa ser mediatizada. Crises econômicas não geram, automaticamente, crises políticas, muito embora elas criem "um terreno mais favorável para a difusão de certos modos de pensar, de formular e de resolver as questões que afetam todo o desenvolvimento posterior da vida estatal" (GRAMSCI, 1975, p. 1587 ). A campanha antiestatista anunciava, através de seu conteúdo generalizante, um novo modo de "pensar, formular e resolver as questões", o início de uma superação do patamar econômicocorporativo ao qual haviam se limitado, até então, as reivindicações empresariais.

O questionamento dos empresários não os colocou claramente no campo da oposição. Os vínculos com o esquema situacionista foram, em larga medida, preservados (DINIZ, 1984, p. 23) e, como alertou Cardoso, rapidamente os empresários voltaram a apoiar, de maneira decidida, o regime militar (CARDOSO, 1983). Tudo isso é 
verdade, mas também o é afirmar que um passo importante para a formulação de um novo projeto do empresariado havia sido dado.

Esse novo modo de agir empresarial tornouse ainda mais evidente durante as greves do $\mathrm{ABC}$, em 1978. Reivindicando um aumento salarial em torno de $20 \%$, dois mil trabalhadores metalúrgicos da Saab-Scania promoveram, em 12 de maio daquele ano, o início de uma grave que iria marcar época. Foram acompanhados por 14 mil metalúrgicos da Mercedes-Benz e 11 mil da Ford. Também houve paralisações na Cofap, Phillips, Otis e Motores Perkins, entre outras. Ao longo daquele ano, cerca de meio milhão de trabalhadores realizaram greves e no ano seguinte a cifra atingiu 3241 500 trabalhadores (ANTUNES, 1995, p. 12) ${ }^{4}$.

As greves que tiveram lugar no $\mathrm{ABC}$ paulista no final da década de 70 marcam o início de um amplo movimento contra a superexploração do trabalho e a legislação política repressiva, que atrelava o movimento sindical ao Estado e cerceava as formas de representação política dos trabalhadores. Esse movimento alteraria profundamente a relação de forças entre as classes, colocando em primeiro plano a chamada "questão sindical".

As reações do empresariado a esse movimento não demoraram a manifestar-se. No dia 26 de junho de 1978, poucos dias depois, portanto, do início das greves, oito líderes empresariais divulgavam um documento político intitulado Primeiro documento dos empresários. Os signatários do documento haviam sido eleitos em consulta a 5 mil empresários de todo o país, realizada pelo jornal Gazeta Mercantil. Faziam parte do chamado "grupo dos oito": Cláudio Bardella, ex-Presidente da ABDIB e Diretor-Presidente do grupo Bardella; Severo Gomes, ex-Ministro da Indústria e Comércio e Diretor-Presidente do grupo Parayba; José Mindlin, Diretor da FIESP e Diretor-Presidente da Metal Leve; Antônio Ermírio de Morais, DiretorPresidente do grupo Votorantin; Paulo Villares, exPresidente do Instituto Brasileiro de Siderurgia e Diretor do grupo Villares; Paulo Velinho, Diretor da Associação Brasileira da Indústria de Aparelhos Elétricos e Eletrônicos (ABINEE), vice-Presidente da CNI e Diretor do grupo Springer-Admiral; Laerte Setúbal Filho, Diretor-Presidente do Grupo

4 Uma análise mais detalhada desse movimento pode ser encontrada em Antunes (1992).
Duratex, e Jorge Gerdau Johanpeter, Diretor do grupo Gerdau. Apenas Augusto Trajano de Azevedo Antunes e Amador Aguiar, do Bradesco, estavam entre os eleitos e não assinaram o documento (DINIZ, 1984, p. 42; MOTTA, 1979).

O documento marcava uma importante inflexão no tratamento por parte dos empresários de temas delicados como a questão sindical. Afirmavam seus signatários que "Qualquer política social conseqüente deve estar baseada numa política salarial justa, que leve em conta, de fato, o poder aquisitivo dos salários e os ganhos de produtividade médios da economia. A partir deste patamar, poderse-ia, então, atender às diferenças setoriais, abrindo espaço para a legítima negociação entre empresários e trabalhadores, o que exige liberdade sindical, tanto patronal quanto trabalhista, dentro de um quadro de legalidade e de modernização da estrutura sindical" (apud MOTTA, 1978, p. 126).

Fazendo um paralelo, clássico no pensamento liberal, entre a iniciativa privada e o regime democrático, os empresários deixaram claro que consideravam esse regime o mais conveniente para "absorver tensões sem transformá-las em um indesejável conflito de classes" (idem, p. 127).

As inesperadas afirmações desses empresários provocaram reações de vários tipos em seu meio. Surpreendentemente não faltaram aqueles que consideraram o documento "conservador", como Carlos Reynaldo Mendes Ribeiro, presidente do Instituto de Desenvolvimento Empresarial do Rio Grande do Sul (O DOCUMENTO DOS OITO, 1978). Ao longo do ano, porém, com a expansão do movimento grevista, as vozes empresariais foram assumindo um tom cada vez mais moderado ${ }^{5}$. A moderação pode ser claramente percebida no documento divulgado pelos empresários eleitos pelo Fórum Gazeta Mercantil do ano de 1978. Seguindo o exemplo dos líderes do ano anterior, esses empresários publicaram um documento mas, desta vez, "um tom abaixo", como ressaltou reportagem da revista Veja (UM TOM ABAIXO, 1978) ${ }^{6}$.

\footnotetext{
5 Em setembro de 1978 a revista Veja contabilizava os grevistas daquele ano na indústria em 274708 , representando 6054 horas paradas. Em média, as greves conquistaram reposições salariais de 13\% e antecipações de 12\% (EFEITOS DA NEGOCIAÇÃO, 1978).

6 A lista dos líderes de 1978 tem poucas alterações se comparada com a de 1977, o que ressalta que na verdade trata-se de uma mudança de posição.
} 
O "tom moderado" era na verdade um claro recuo. Os empresários pareciam adotar a máxima do peronismo dos anos 1950: "desencillar hasta que aclare". Ao invés de sinalizar um projeto abrangente de redefinição da ação empresarial, os líderes de 1978 lavaram as mãos e afirmaram: "desincumbir-se com humildade da grave responsabilidade de traduzir as aspirações do empresariado nacional com relação à melhor maneira de constituir neste país uma sociedade desenvolvida e justa" (ibidem).

Pouco moderada foi, entretanto, a atitude da FIESP e de alguns empresários durante as greves do segundo semestre. É bom lembrar que, já em junho, líderes da FIESP conclamavam "a força repressiva do governo" (apud CRUZ, 1997, p. 341). Tal afirmação despertou muitas críticas no meio empresarial. Criticas semelhantes, porém, não recebeu a circular da FIESP orientando as empresas para o enfrentamento das greves. A circular aconselhava as empresas a não fazerem acordos diretos com os empregados; a fecharem os portões, para evitarem a greve no interior da fábrica, e a suspenderem os grevistas ou, até mesmo, "dispensar certo número de pessoas por justa causa" (idem, p. 348.)

A súbita adesão à democracia expressa pelo "documento dos oito", deve ser, portanto, considerada de maneira cautelosa. O ano de 1978 foi todo ocupado pelas articulações para a sucessão do General Ernesto Geisel e as incertezas da política de "abertura", por um lado, e, por outro, pela súbita retomada do movimento grevista. A ação empresarial acompanhará o vai-vem da conjuntura, ora avançando, ora recuando; ora vendo no movimento sindical um potencial aliado, ou, ao menos, um interlocutor necessário; ora, ainda, denunciando o caos e a desordem.

O que permanece desse vai-vem e o que unifica os empresários? Permanece uma exigência contínua e unitária de materialização, nas ações governamentais, dos anseios do empresariado. Demanda que é claramente visível no documento "dos oito" e seu clamor por um sistema político que permita "a participação de todos" (apud MOTTA, 1979, p. 126), mas que é, também, uma reivindicação presente nas afirmações do Presidente da FIESP, Theobaldo De Nigris, publicadas na imprensa no mês de setembro: "a busca de uma participação efetiva por parte do empresariado nas discussões de problemas nacionais é uma meta antiga, ainda não atingida. A entidade, portanto, reivindica uma participação oficial na discussão dos principais assuntos econômicos do país" (apud CODATO, 1997, p. 297).

As posições defendidas pelo "grupo dos oito" logo se manifestaram no interior da FIESP. Uma dura batalha travou-se no interior da Federação paulista pelo seu comando. De um lado Luís Eulálio de Bueno Vidigal, representando uma proposta de transformação da ação empresarial. Do outro, Theobaldo De Nigris, buscando mais um mandato. A contenda acabou quando De Nigris retirou sua candidatura, evitando aquela que seria a primeira eleição disputada para a Presidência da FIESP.

O ano de 1979 terminou, assim, com a incorporação do "grupo dos oito" ao comando da FIESP. Os empresários que constituíam esse grupo, representantes, em sua maioria, do setor mais dinâmico da indústria na década de 1970 - a indústria metal-mecânica e a eletro-eletrônica -, assumiram a entidade com um programa que visava a instaurar um padrão mais autônomo no relacionamento com o governo, rompendo a dependência característica do período anterior. No programa desses empresários encontrava-se a busca de uma colaboração mais intensa com o Executivo, procurando uma solução negociada para a crise econômica e política.

Mais do que uma mudança de atitude em relação ao regime militar, eles procuravam reforçar o poder de barganha frente ao governo federal. A atitude desses empresários não representava uma ruptura decisiva do empresariado com o regime; também não traduzia uma nova hegemonia burguesa, como chegou a interpretar Bresser Pereira (1978). A inexistência de uma ruptura decisiva do empresariado com o regime autoritário pode ser ilustrada pela sua atitude frente à questão operária, atitude essa que mantinha a linha de atuação definida durante a década anterior (DINIZ, 1985).

\section{EM BUSCA DE ALTERNATIVAS À CRISE DE REPRESENTAÇÃO}

Direção política e ideológica implicam formas institucionalizadas e eficazes de representação. O monopólio da representação não é necessário, embora um certo grau de homogeneidade seja requerido. O critério fundamental, entretanto, é o da direção efetiva, ou seja, os "representados" devem identificar-se, em grande medida, com os "representantes". 
Torna-se, assim, evidente que o exercício da hegemonia é incompatível com uma crise da representação. Ou seja, aquilo que geralmente é denominado crise de representação, ou crise de autoridade, é, na terminologia aqui utilizada, crise de hegemonia. A crise de representação do empresariado brasileiro manifestou-se com toda sua força na década de 1980 . Seu sinal mais evidente foi a multiplicação de entidades empresariais e as crises internas permanentes ocorridas no interior das antigas federações e confederações.

Durante os anos 1960 e 1970 ocorreu, como já foi visto, um aperfeiçoamento do sistema de representação empresarial, com a consolidação de entidades civis criadas com o objetivo de articular os interesses setoriais do empresariado. Essas associações civis, entretanto, não se chocavam com as tradicionais federações e confederações patronais. Antes de mais nada, a estrutura paralela visava a adaptar a representação empresarial à complexa rede de instituições estatais criada pelo governo federal para a definição de diretrizes econômicas. Essa rede de instituições permitiu uma participação direta dos empresários no aparelho estatal. A participação nessas instituições governamentais ou para-governamentais restringia-se, entretanto, à definição de políticas localizadas, relacionadas aos interesses mais imediatos dos setores representados. A estrutura paralela de representação não concorria, portanto, com a estrutura tradicional, mas a completava.

O surgimento de um grande número de entidades empresariais na década de 1980 rompeu esse padrão de representação e fragmentou ainda mais a representação de interesses patronais. Certamente a estrutura corporativa da representação empresarial e a possibilidade de acesso direto às altas esferas decisórias contribuíram para a fragmentação associativa, conforme analisado por Schneider (1997-1998) e Weyland (1998). Mas, para além das raízes estruturais, é preciso perceber o contexto no qual essas novas associações surgiram: ele definiu-se por uma crise da representação empresarial alimentada pela combinação da crise econômica com a crise política que marcara os anos 1980.

As novas entidades surgem apresentando as respostas mais variadas a esse contexto, expressando a ausência de um consenso empresarial. Ao contrário das federações e confederações, elas têm vocação mais abrangente. Organizam empre- sários de diversos ramos. Articulam interesses mais amplos. Apresentam-se como uma alternativa à estrutura tradicional de representação patronal. Dentre essas entidades, têm-se destacado o Instituto Liberal, o Instituto de Estudos para o Desenvolvimento Industrial (IEDI) e o Pensamento Nacional das Bases Empresariais (PNBE), associação que, como já anunciado, é objeto do presente trabalho.

Criado em 1983, o Instituto Liberal tem por objetivo a difusão da concepção de mundo liberal e seus valores: em primeiro lugar a primazia das leis de mercado sobre a ação estatal, mas também, e daí decorrentes, a liberdade como fundamento do Estado de Direito, a defesa da iniciativa privada e a igualdade de todos perante a lei ${ }^{7}$.

O Instituto Liberal não está preocupado, pois, com a representação de setores do empresariado, nem com a formulação de uma política industrial e sim com a difusão de uma ideologia. Para marcar essa diferença, o Instituto Liberal não se apresenta como uma associação de empresários e sim como uma associação civil, muito embora sejam empresários a maior parte de seus membros e daqueles que contribuem financeiramente.

Dentre as empresas que contribuem financeiramente com a entidade estão alguns dos mais poderosos grupos econômicos do país. Com o Instituto Liberal de São Paulo, por exemplo, contribuem nove grandes empresas estrangeiras em operação no Brasil e quinze dos maiores grupos econômicos nacionais ${ }^{8}$.

Com vistas a difundir seu ideário, o Instituto Liberal tem recorrido a um conjunto de iniciativas variadas. No Rio de Janeiro, a entidade concentrou seus esforços no acompanhamento de políticas

\footnotetext{
7 Escreve-se Instituto Liberal, no singular, por uma questão de economia de esforço. $\mathrm{Na}$ verdade existem institutos estaduais coordenados por um Conselho Nacional de Institutos Liberais. Além de citado em um número considerável de estudos sobre o empresariado, há, sobre o Instituto Liberal, a pesquisa em andamento de Denise Barbosa Gros. Resultados preliminares dessa pesquisa podem ser encontrados em Gros (1993).

8 Os grupos transnacionais são: Alcoa Alumínio, Carrefour, Ciba-Geigy, Citibank, Dow Química, Gessy Lever, Hoechst, Nestlé, e Rhodia. Dentre as empresas nacionais vale destacar Bradesco, Banco Itaú, Banco de Crédito Nacional, Indústrias Villares, Paranapanema Mineração, Varig e Votorantim (GROS, 1993, p. 142).
} 
públicas e na avaliação de projetos de lei através de publicação mensal específica: Notas. Avaliação de Projetos de Lei. Levantamento feito por Denise Barbosa Gros registrou, até agosto de 1996, 65 números publicados, abordando desde o direito de greve até o orçamento da União. Já em São Paulo, a ênfase recai na atividade educacional, seja através de convênios com universidades, seja na formação de jornalistas e de professores do ensino básico.

O Instituto de Estudos para o Desenvolvimento Industrial (IEDI) tem propósitos e formas de atuação diferentes dos do Instituto Liberal. Criado em 23 de maio de 1989, ele representa um conjunto de interesses restritos à indústria e à política industrial $^{9}$. Em documentos da entidade, sua missão é assim resumida: "Participar em parceria com o Estado e Entidades com interesse na Indústria, da formulação e implementação de Política de Desenvolvimento Industrial que, como parte de um Projeto Nacional, tenha como objetivos: participação crescente da Indústria brasileira na produção mundial da indústria; aumento da produção de bens com maior valor agregado e conteúdo tecnológico; crescimento continuado da riqueza nacional. Agir para que o crescimento econômico resultante propicie melhoria das condições de vida da sociedade brasileira, tornando-a mais justa e igualitária" (IEDI, s/d, p. 2; grifos no original).

Participaram da fundação da entidade e têm mantido nela destacada atuação importantes industriais, representando empresas e grupos de diversos ramos, principalmente paulistas, mas não só. Entre elas merecem destaque, por sua importância, Aracruz Celulose, Cofap, Coldex Frigor, Gradiente Eletrônica, Metalúrgica Gerdau, Indústrias Votorantim e Grupo Monteiro Aranha.

Entre os sócios-fundadores e integrantes do Conselho Administrativo, nove apareceram nas listas de empresários destacados anualmente pela Gazeta Mercantil durante a década de 1980. Também dá mostras da influência dos membros do IEDI a participação destes à frente de entidades

9 Embora citado em artigos de Eli Diniz, Renato Boschi, Sebastião Velasco e Cruz, Schneider, Weyland e Denise Barbosa Gros que iluminam um ou outro aspecto da entidade, não existe, ainda, estudo exaustivo sobre o Instituto de Estudos para o Desenvolvimento Industrial. O único artigo dedicado exclusivamente ao IEDI é o de Kingston (1998). como a Associação Brasileira da Indústria de Máquinas e Equipamentos (ABIMAQ), a Associação Brasileira da Indústria Eletro-Eletrônica (ABINEE) e a Associação Brasileira para o Desenvolvimento da Indústria de Base (ABDIB) (DINIZ, 1993, p. 124).

Em entrevista ao jornal Folha de São Paulo, o atual presidente da entidade, Eugênio Staub, da Gradiente, resumiu assim as "crenças fundamentais" da entidade: "A primeira é que o desenvolvimento econômico e social está intimamente ligado ao desenvolvimento da indústria, e a segunda é que nós empresários, como membros da elite, temos a responsabilidade de desenhar e construir o futuro do país" (ENTIDADE QUER MAIS INVESTIMENTO, 1997).

Comportando-se como verdadeiros "intelectuais condensados", formuladores de políticas e mega-empresários, os associados do IEDI estão engajados na criação de estratégias de desenvolvimento, tendo como pressuposto que há uma crise estrutural decorrente do esgotamento do "antigo modelo de industrialização por substituição de importações" inaugurado na década de 1940 e da ausência de um projeto alternativo para a década de 1990 (IEDI, s/d, p. 10). Desde o governo Collor, eles vêm insistindo na necessidade de uma política industrial que permita uma inserção não passiva no mercado mundial. Em 1996, o então Presidente do grupo Ultra e do IEDI, Paulo Cunha, afirmava que a globalização era "um processo de grande intensidade, uma tempestade, e o Brasil abriu seu mercado de forma hesitante, incompleta e mal planejada. Tudo caracterizando, portanto, muito mais um vôo de borboleta do que o salto de um tigre" (EMPRESÁRIO ATACA, 1996). Cunha defendia a necessidade de uma política afirmativa elaborada a "quatro mãos", entre o setor produtivo e o governo.

Empenhado em elaborar essa alternativa, o IEDI tem sido encarado por empresários e pela imprensa como um “'think tank' de política industrial" (SEMLER, 1996), um grupo de grosso calibre, "seja pelo volume de negócios, seja pela massa encefálica" (ROSSI, 1994). Não se trata, portanto, de um grupo que almeja representar o empresariado ou uma parcela dele, mas de uma entidade voltada para a elaboração de uma política empresarial: "o objetivo da criação do IEDI era ambicioso: promover estudos visando [a] revelar as novas questões relevantes para a economia e a indústria 
do país e, transcendendo o diagnóstico, agir para dar-lhes resposta adequada" (IEDI, s/d, p. 11).

O que aqui cabe ressaltar, entretanto, é que nem o propósito explícito de não competir com as organizações tradicionais na representação do empresariado, nem o volume dos negócios ou da "massa encefálica", garantiram o espaço do grupo no interior da estrutura tradicional de representação do empresariado. Segundo um empresário entrevistado por Eli Diniz e Renato Boschi, "o caso do IEDI é clássico. Inicialmente, o grupo de empresários que fundou o IEDI, [...] todos nós tentávamos operar esse projeto do IEDI dentro da FIESP, dentro da CNI e encontramos dificuldades operacionais imensas. Então, pareceu mais eficaz constituir uma organização especificamente voltada para essa atividade, para essa finalidade a que nos propusemos" (DINIZ \& BOSCHI, 1993, p. 111).

O PNBE difere profundamente das entidades acima mencionadas. Em primeiro lugar, porque ele almeja representar um setor do empresariado. Em segundo lugar, porque não é uma entidade voltada explicitamente para a elaboração de propostas ou para a difusão de uma ideologia, mas uma associação de empresários com vistas à ação.

A entidade nasceu com pompa e circunstância. No início do mês de junho de 1987, cerca de 2600 empresários compareceram ao Anhembi, em São Paulo, para participar de uma audiência pública com o então Ministro da Fazenda Luiz Carlos Bresser Pereira (PNBE, s/d; 1998). A reunião foi convocada com objetivo de debater as propostas a serem apresentadas pelos empresários à Assembléia Constituinte. Manifestação como essa no meio empresarial nunca tinha sido vista, ainda mais que a reunião havia sido convocada por algumas jovens lideranças, cujos nomes só eram até então conhecidos por aqueles que acompanhavam o diaa-dia dos sindicatos patronais.

A reunião, ato de nascimento do $\mathrm{PNBE}$, não deixou texto ou documento conhecido. Ocupou, apenas, algumas colunas dos jornais (CRÍTICAS, SUGESTÕ̃ES, RISOS, 1987; 'VOU AUMENTAR OS IMPOSTOS', 1987; O SIGNIFICADO POLÍTICO, 1987; BRESSER DIZ, 1987; MINISTRO RECEBE APOIO, 1987). E, na verdade, poucos de seus participantes lembramse hoje do conteúdo real do debate. Lembram-se, entretanto, de maneira muito viva, do impacto que ela causou no interior da estrutura de representação empresarial.
A oposição da Federação das Indústrias do Estado de São Paulo (FIESP) à organização desses empresários foi forte. O então presidente da Federação, Mário Amato, havia sido convidado a liderar o evento. Mas não aceitou a proposta. Pelo contrário: interpretou a reunião como uma disputa "pelo poder" na entidade e organizou um boicote ativo. Enviou um documento confidencial aos presidentes dos sindicatos da indústria paulista, orientando-os a marcarem reuniões no horário do evento (PNBE ASSUSTA, 1987).

Emerson Kapaz, que participou ativamente da organização do ato, narrou assim a reação de Amato: "ele se recusou a estar presente, tivemos uma reunião até dura na FIESP, que eu me lembro bem, e ele não queria de jeito nenhum estar presente. Deixou que o CIESP [Centro das Indústrias do Estado de São Paulo] ajudasse a mobilizar o empresariado" (KAPAZ, 1996).

Essa reação da cúpula da FIESP provocou um confronto entre esses empresários e a entidade. As animosidades atingiram seu ápice quando Mário Amato destituiu, da diretoria da FIESP, Paulo Butori, Diretor-Adjunto do Departamento de Estatística; Oded Grajew, Diretor-Adjunto do Departamento de Expansão Social; e Bruno Nardini, vicePresidente do BNDES e Diretor-Adjunto do Departamento de Cooperação Sindical, todos eles membros ativos do PNBE (PNBE FORA, 1988).

A ausência de um espaço dentro da FIESP levou o movimento a optar pela institucionalização, criando formalmente o PNBE em 1990. Para um dos entrevistados, "as pessoas que compuseram o PNBE sentiam o espaço na FIESP muito limitado para a ampliação desta discussão de sociedade, do papel das pessoas, essas questões estruturais todas que a gente tem que resolver" (ANÔNIMO, 23.jan.1996).

Como explicar o surgimento do PNBE e o fracionamento cada vez maior da representação empresarial? Como elucidar essa verdadeira "rebelião das bases"? Quais suas reais motivações?

Classificando as novas formas de organização do empresariado, Sebastião Velasco e Cruz aponta que o surgimento do PNBE está intimamente vinculado ao "surgimento de propostas mobilizadoras endereçadas aos empresários, como pessoas físicas, com o duplo propósito de veicular junto à opinião pública e às autoridades pontos de vistas sub-representados nas estruturas organiza- 
tivas institucionalizadas e de maximizar a influência de seus promotores no interior destas" (CRUZ, 1997a, p. 136).

Nas reclamações sobre o "espaço limitado" e nas reivindicações de uma reformulação do processo de tomada de decisões no interior da FIESP e da "consulta às bases" é possível ler, sem muito esforço, um clamor por uma representatividade maior. Trata-se de uma tentativa de superação do abismo que separa "representantes" e "representados", portanto, uma tentativa de superar a crise de representatividade.

\section{PEQUENOS NEGÓCIOS E GRANDES INFLUÊNCIAS}

Do grupo original que convocou a manifestação do Anhembi, em 1987, nem todos aderiram ao projeto de construção do PNBE. Paulo Butori e Luís Carlos Delben Leite continuaram a exercer uma atividade de liderança nos marcos da FIESP, dos sindicatos e das associações setoriais. Joseph Couri, por sua vez, embora continue associado ao PNBE, tornou-se, com o passar dos tempos, uma ativa liderança dos pequenos e micro-empresários, participando da fundação do Sindicato da Micro e Pequena Indústria (SIMPI), em 1987.

Emerson Kapaz e Oded Grajew foram, daquele grupo original, os que abraçaram de maneira mais decidida o projeto de construção de uma nova entidade empresarial. Não ficaram, entretanto, sós. Com o passar dos anos somaram-se ao projeto de construção do PNBE alguns importantes industriais paulistas. Dentre eles merecem destaque: da indústria metalúrgica, Sérgio Mindlin, então Diretor da Metal Leve; Mário Bernardini, da empresa metalúrgica MGM e da Associação Brasileira da Indústria de Máquinas e Equipamentos (ABIMAQ); Adauto Ponte, da Associação Brasileira da Indústria de Fundição (ABIFA), e Hélio Mattar, ex-Diretor da Dako Fogões e, posteriormente, Secretário do Ministério do Desenvolvimento $^{10}$. Da construção civil: Eduardo Capobianco, posteriormente Presidente do Sindicato da Construção do Estado de São Paulo (SINDUSCON); Hugo Marques da Rosa, da Método Engenharia; e Cláudio Fortes, da João Fortes Engenharia S/A. Salo Seibel, do Grupo Madelânia,

10 Mário Bernardini e Adauto Pontes romperam em 1992 com o PNBE e integraram a chapa de Moreira Ferreira às eleições do CIESP/FIESP daquele ano. e Guilherme Peirão Leal, da Natura, também merecem destaque ${ }^{11}$.

Posteriormente, outros pequenos e médios empresários, principalmente do setor de serviços, iriam se somar ao projeto. São empresários do comércio, como Alberto MacDowell de Figueiredo, ex-Diretor da BRTR Comércio Exterior e atual Diretor de Recursos Humanos da Nossa Caixa Nosso Banco, e Jack Strauss, da Sofá \& Companhia; advogados, como Percival Maricatto, que também tem empreendimentos em bares e restaurantes, e, principalmente, consultores, como Mário Ernesto Humberg, diretor da CL-A Comunicações; Jorge Hori, da Planasa; Betty Abramowicz, da Ecoplan; Clarice Pechman, do Bureau de Estatísticas e Estratégias; Dilermando Allan Filho, da Dyal Engenharia Consultores, e Elaine Saad, da Saad Fellipelli Recursos Humanos.

$\mathrm{O}$ setor financeiro encontra-se sub-representado, o que não é de se estranhar, devido às recorrentes críticas que a entidade dirige à "especulação" e aos "rentistas". Identificou-se, ao longo da pesquisa, apenas seis banqueiros, entre os quais José Baía Sobrinho, Presidente do Banco Pontual, e Marco Antônio de Queiroz, do Banco Antônio de Queiroz. Mas tais empresários nunca ocuparam posições importantes na entidade.

Por fim três outros empresários merecem destaque, seja pela dimensão de sua atividade empresarial, seja pela liderança exercida na entidade: Ricardo Young, Presidente do Yázigi International;

11 O currículo de Salo Seibel, 1ํㅡㄹ Coordenador-Geral da entidade na gestão 1994-1995, dá uma amostra da intensa atividade desses industriais na estrutura de representação do empresariado. Quando da sua candidatura à Coordenação do PNBE, Seibel apresentou o seguinte currículo: vicePresidente da ABDIB (indústrias de base); Diretor do SINDSUPER (tratamento de superfícies); membro do Conselho Diretor da Ação Comunitária do Brasil e da ABRASCA (companhias abertas); do Conselho de Administração da Bovespa; vice-Presidente da ABRIPLA (laminados) e diretor da ABIMA (painéis de madeira); titular do Conselho de Recursos do Sistema Financeiro Nacional; Diretor-Geral da bolding do Grupo Madelânia (que controla a Formica e Leo Madeiras, entre outras); Diretor-Presidente da Satpel e da Madeplac; Presidente do Conselho de Administração e Diretor da Brasimet; Diretor vice-Presidente da Formiline; membro do Conselho de Administração da Nova Gasômetro, empresa controladora do São Paulo Market Center, Presidente da Comissão de Assuntos Parlamentares do CIESP-Zona Sul. 
Pedro de Camargo Neto, ex-Presidente da Sociedade Rural Brasileira, e Paulo Anthero Barbosa, pequeno empresário da indústria cinematográfica. Camargo Neto e Young já ocuparam a posição de Primeiro Coordenador-Geral da entidade e Barbosa disputou em 1994 a eleição para tal posto, perdendo a indicação para Salo Seibel.

Um rápido levantamento dos empresários vinculados ao PNBE permite identificar que, durante seus primeiros anos, a presença de industriais era muito forte. Nascido no interior do complexo FIESP/CIESP, o PNBE naturalmente vinculou sua origem à indústria, aparecendo como um setor de oposição à Federação. Segundo um entrevistado, "como o PNBE nasceu de um grupo de industriais que atuavam na política dentro da FIESP ele foi taxado inicialmente de um grupo dissidente da FIESP, de oposição à FIESP. Na verdade não é, ele não tinha esse propósito, tinha o propósito de criar alguma coisa diferente de fazer uma forma diferente de ação. Ao longo dos anos isso foi ficando cada vez mais claro quando o PNBE aumentou muito a participação de em-presários de outros setores que não da indústria e se ocupou de questões mais amplas no cenário nacional, como a questão de reformas políticas e a questão de educação" (ANÔNIMO, 26.jun.1996).

O predomínio dos industriais transpareceu claramente nos primeiros anos de institucionalização da entidade. Os oito primeiro coordenadores iniciais da entidade foram industriais, como pode ser visto no quadro abaixo:

QUADRO 1 - Relação dos coordenadores gerais da entidade (1990/1997)

\begin{tabular}{|c|c|c|}
\hline Primeiro coordenador & Segundo coordenador & Data da eleição \\
\hline Oded Grajew & Emerson Kapaz & Junho/1990 \\
\hline Emerson Kapaz & Oded Grajew & Dezembro/1990 \\
\hline Sérgio Mindlin & Eduardo Capobianco & Dezembro/1991 \\
\hline Eduardo Capobianco & Hélio Mattar & Julho/1992 \\
\hline Hélio Mattar & Ricardo Vacaro & Dezembro/1992 \\
\hline Emerson Kapaz & Paulo Anthero Barbosa & Julho/1993 \\
\hline Emerson Kapaz & Paulo Anthero Barbosa & Dezembro/1993 \\
\hline Emerson Kapaz & Paulo Anthero Barbosa & Julho/1994 \\
\hline Pedro de Camargo Neto & Eduardo Schubert & Dezembro/1994 \\
\hline Salo Seibel & Jack Strauss & Junho/1995 \\
\hline Salo Seibel & Jack Strauss & Janeiro/1996 \\
\hline Ricardo Young & Mario Ernesto Humberg & Junho/1996 \\
\hline Eduardo Capobianco & Betty Abramowicz & Abril/1997 \\
\hline
\end{tabular}

Fonte: PNBE (1998).

Entretanto, analisando as publicações da entidade e realizando entrevistas foi possível perceber que, ao longo dos anos 1990, houve um claro deslocamento da composição da entidade. Aos poucos o setor de serviços passava a predominar. Em 1996, o Secretário-Executivo da entidade, Alfredo Sette, informou que a maioria dos associados eram pequenos e médios empresários do setor de serviços. Já Emerson Kapaz, um dos organizadores do ato do Anhembi, afirmou que tal manifestação foi majoritariamente industrial, mas, atualmente o PNBE tem "uma tendência muito forte de serviços. Serviços cresceu muito, até por uma mudança da realidade econômica mesmo. Serviços é [sic], hoje, na realidade da economia mundial, um setor que cresce muito. Então a representação de qualquer empresariado tem que passar pela questão de serviço também" (KAPAZ, 1996).

A transformação na composição social da entidade pode ser verificada na lista de empresários que aderiram ao PNBE entre 12 de agosto de 1993 e 25 de fevereiro de 1994, período de grande expansão do número de associados na entidade (Pensamento empresarial, 1993; 1994). Dos 185 
associados listados, apenas um exercia atividade em empresa industrial de porte, Hugo Marques da Rosa, da Método Engenharia ${ }^{12}$. A grande maioria dos novos associados era do setor de serviços. A eleição do ruralista Pedro de Camargo Neto para a primeira Coordenação-Geral, em 1994, indicou que, aos poucos, a entidade estava se afastando de seu berço industrial. Mas foi a eleição de Ricardo Young para o cargo que consolidou esse novo perfil, o que não escapou aos observadores mais atentos na época (OUTRAS BASES, 1996).

A lista de associados do PNBE publicada em 1998 dá conta dessa predominância do setor de serviços. Nesse ano, mais de três quartos dos sócios do PNBE estavam vinculados ao setor terceário da economia. Dos 359 associados, 237 pertenciam ao setor de serviços, 79 à indústria, 39 ao comércio e 9 ao setor agropecuário (PNBE, 1998).

Além de um deslocamento para o setor de serviços, é possível verificar, também, um predomínio de pequenos e médios empresários. Ao contrário da tendência à tercearização da entidade, a baixa presença de grandes empresários é uma marca da entidade desde sua fundação. Os industriais que criaram o PNBE destacavam-se, com notáveis exceções, mais pelo papel ativo nas associações e sindicatos empresariais do que pelo volume de seus negócios. Emerson Kapaz era proprietário da Elka e Oded Grajew da Grow, empresas de porte médio da indústria de brinquedos.

A liderança que ambos exerceram no PNBE e no meio empresarial supera em muito a dimensão de seus negócios. Em 1986, Kapaz foi eleito presidente do Sindicato das Indústrias de Instrumentos Musicais e de Brinquedos do Estado de São Paulo e reeleito em 1989. Várias vezes coordenador do PNBE, Kapaz participou ativamente das gestões por um entendimento nacional durante o governo Collor, quando adquiriu projeção nos meios de comunicação. Em 1991, seu nome aparecia pela primeira vez na lista de líderes empresariais elaborada anualmente pela Gazeta Mercantil através de consulta a homens de negócios de todo o país. Ocupava aí a quinta posição. No ano seguinte, já era o segundo da lista, passando a ocupar

12 Segundo o Balanço anual da Gazeta Mercantil 1998, a Método Engenharia é líder do segmento de edificações comerciais, com uma receita líquida de R $\$ 125$ milhões (GAZETA MERCANTIL, 1998, p. 296). a posição de mais votado nos anos de 1993 e 1994.

Paradoxalmente, o Balanço anual da Gazeta Mercantil 1994/1995, que o indicou como líder empresarial do ano, não registra sua empresa, a Elka Plásticos. Naquele ano a imprensa noticiava que o faturamento da Elka havia sido de US\$20 milhões e que a empresa possuía 580 funcionários (ELEIÇÃO NA FIESP, 1992). Foi, pois, na condição de dirigente empresarial e não na de homem de negócios que Kapaz lançou sua candidatura à presidência da FIESP, em 1992.

Grajew, por sua vez, ocupou a primeira coordenação do PNBE na fundação da entidade, bem como a presidência da Associação Nacional da Indústria de Brinquedos (ABRINQ). Foi, também, coordenador do Movimento pela Ética na Política e criou e lidera a Associação de Empresários pela Cidadania (Cives), que reúne empresários vinculados ao Partido dos Trabalhadores. Nos últimos anos, seu nome ganhou repercussão devido à sua liderança na Fundação Abrinq pelos Direitos da Criança (O CHATO QUE FUNCIONA, 1997). Quanto aos negócios... bem, aí a história parece ser outra. A empresa que ajudou a fundar, a Grow Jogos e Brinquedos, apresentou, em 1997, uma receita líquida de $\mathrm{R} \$ 39$ milhões e um patrimônio líquido de R\$ 1 milhão. Mas a empresa há muito não contava com Grajew à sua frente. Em 1988, ele deixou as funções executivas de sua empresa de brinquedos: "queria mais tempo para mim", explicou. E, em 1994, retirou-se definitivamente do negócio, vendendo sua participação para o sócio Valdir Rovai (ibidem).

Nesse mundo de pequenos e médios empresários e grandes influências, Sérgio Mindlin e Salo Seibel parecem ser as exceções. Sucessor do lendário José Mindlin no comando da Metal Leve, Sérgio ficou à frente da empresa até 1996, quando foi vendida ao grupo alemão Mahle. No ano posterior à sua venda, a Metal Leve fechou o ano com um patrimônio líquido de $\mathrm{R} \$ 120$ milhões e um faturamento anual de R \$229 milhões, quarto melhor resultado do setor de componentes e motores, segundo o Balanço anual Gazeta Mercantil. Mindlin, o filho, já ocupou a primeira coordenação do PNBE e atualmente é membro do Conselho Diretor da Fundação ABRINQ pelos Direitos da Criança. Na lista dos associados já citada, Sérgio Mindlin figura agora como prestador de serviços de consultoria de gestão e de comunicação.

Salo Seibel, por sua vez, tem um extenso 
currículo de atividades empresariais, como já foi mostrado, e esteve à frente do PNBE nos anoschave de 1994 e 1995, além de ser, atualmente, conselheiro do IEDI. A principal empresa do Grupo Madelânia, do qual é Diretor Geral, a Leo Madeiras, liderava o setor de material elétrico e de construção do Balanço anual Gazeta Mercantil, no ano de 1998, com uma receita líquida de $\mathrm{R} \$$ 111 milhões e um patrimônio líquido de $\mathrm{R} \$ 43$ milhões.

No pequeno grupo de grandes empresários do PNBE é preciso acrescentar, mais pelo porte de suas empresas do que pela participação na entidade, os nomes de Guilherme Peirão Leal e Antônio Luiz da Cunha Seabra, da Natura. Ambos viram sua empresa quadruplicar o faturamento nos seis primeiros anos da década de 90 , tornando-se a quarta maior empresa brasileira do setor de higiene e limpeza, com 3 mil funcionários, $180 \mathrm{mil}$ vendedores e um faturamento anual de US\$ 580 milhões (ATÉ ONDE A NATURA, 1997, p. 118). Merecem destaque, também, Celso Varga, da Freios Varga S/A; Sérgio Coimbra, da Cia. Cacique de Café Solúvel; e um surpreendente José Roberto Marinho, do Sistema Globo de Rádio.

O predomínio dos pequenos e médios empresários do setor de serviços pode indicar que a entidade serviu para organizar setores que até então não viam suas demandas de representação serem atendidas pelos sindicatos, federações e confederações patronais. É o que dá a entender Emerson Kapaz, por exemplo. Questionado sobre o predomínio dos pequenos e médios empresários no PNBE, Kapaz respondeu: "É porque no fundo nós surgimos com essa forte preocupação com uma questão chamada democracia, porque se você representa o empresariado de uma forma democrática mesmo, a tendência é que você tenha um grande peso de pequena e média empresa, $95 \%$ das empresas do Brasil são micro, pequenas e médias. Só 5\% são grandes. Então você tem 3 milhões e 500 mil empresas desse porte no Brasil. Se você quer representar democraticamente o empresariado como um todo, você vai ter $95 \%$ de pequenas e médias empresas" (KAPAZ, 1996).

\section{EM BUSCA DE UM PROJETO EMPRESA- RIAL ALTERNATIVO}

$\mathrm{O}$ fato de que o PNBE tenha nascido como um movimento preocupado em elaborar as propostas dos empresários para a Assembléia
Constituinte é bastante significativo. Historicamente, esse momento coincidia com a falência do Plano Cruzado e a escalada inflacionária; coincidia também com um incremento da mobilização sindical que procurava, através das greves, recuperar as perdas salariais.

Vários entrevistados ressaltaram que o fracasso do Plano Cruzado está na origem do movimento. A crítica não era dirigida tanto às medidas em si, mas à forma como elas foram implementadas, principalmente após as eleições de 1986, quando o governo procedeu à liberação dos preços. Segundo Oded Grajew, um dos fundadores do PNBE, "o plano causou muita euforia mas não deu em nada, porque foi feito de cima para baixo" (PNBE, 1993c).

Concebido a portas fechadas e divulgado sob a forma de Decreto-Lei, o Plano Cruzado reproduziu o estilo tecnocrático de gestão próprio dos governos anteriores. Todas as afirmações a favor da união nacional e ao pacto social realizadas por Tancredo Neves antes da posse não se materializaram em políticas concretas. Tanto a equipe econômica, liderada por Francisco Dornelles, de caris ortodoxo, como os heterodoxos, chefiados por Dílson Funaro, procederam da mesma forma, recusando toda interferência externa e a negociação na elaboração das políticas econômicas.

Daí a contradição: muito embora o Plano não prescindisse do apoio ativo, conclamando à mobilização e à sua defesa, este só tinha a oferecer como atrativo seus fins e não os meios. $\mathrm{O}$ apoio empresarial estava, em grande medida, vinculado às expectativas de contenção da inflação e ao apoio popular que o Plano havia despertado em seus primeiros momentos. Mas essa era uma base frágil para um maior comprometimento com o futuro da política econômica governamental.

Não é lugar, aqui, de analisar as razões do fracasso do Plano Cruzado. Basta apontar que tal fracasso deve-se não só a razões econômicas como também à incapacidade de o governo federal comprometer empresários e trabalhadores com suas metas. Não só os empresários realizaram uma permanente guerra de guerrilhas contra o congelamento de preços, recorrendo a inúmeros artifícios para burlá-lo ou pressionando ininterruptamente o governo para sepultá-lo, como os trabalhadores utilizaram a expansão do consumo e o aquecimento da atividade econômica para reivindicar e 
conquistar aumentos salariais. ${ }^{13}$.

Embora tenha sido escolhido pelo PNBE como o momento-símbolo para o despertar da consciência empresarial, o fracasso do Plano Cruzado coincide cronologicamente com a consolidação do regime democrático no país, através da convocação de uma Assembléia Nacional Constituinte. É, portanto, mais um elo numa cadeia de profundas transformações, não só políticas, como também econômicas e sociais, pelas quais passou a sociedade brasileira na década de 1980 .

Um dos entrevistados manifestou assim essas transformações e seu impacto: "Depois do fim do regime militar, diretas já, aquele movimento todo, o próprio surgimento do movimento sindical em 1983, a CUT em São Bernardo, você começa a ter um engajamento maior, uma participação maior, ou uma busca de uma participação maior da sociedade neste processo. E o Cruzado foi a gota d'água nesse processo, porque ele mostrou que se a gente ficasse dentro dos muros, das empresas, as pessoas que compõem o governo continuariam manipulando o Estado segundo seus próprios interesses, como foi feito no Cruzado" (ANÔNIMO, 23.jan.1996).

A necessidade de organizar o empresariado para garantir a influência deste na Assembléia Nacional Constituinte aparece em outra entrevista: "o empresariado estava desmobilizado para fazer uma articulação consistente e influir nas decisões da Assembléia Constituinte que estava acontecendo, começando a ser discutida em Brasília" (ANÔNIMO, 27.jun.1996).

Dois eram os problemas destacados pelos empresários: a ausência de uma plataforma empresarial que desse conta de todas as questões abordadas na Constituinte e a fraca capacidade de representação das federações e confederações.

A ausência de uma plataforma abrangente pode ser verificada no discurso de Luís Eulálio de Bueno Vidigal, então Presidente da FIESP, na Federação das Indústrias do Estado de Minas Gerais. $\mathrm{Na}$ palestra, Vidigal expôs o programa do empresariado para a Constituinte, salientando que os temas

13 Ao longo do ano, houve 1267 greves e um total de 8,3 milhões de grevistas - 4,5 milhões dos quais no setor privado (CUT, 1994). referentes à iniciativa privada e às entidades patronais diziam respeito à chamada Constituição "econômica". Os temas destacados por Vidigal foram "a definição do papel do Estado no domínio econômico, a forma ou o tipo de economia, o exercício do poder na economia, os direitos e garantias econômicas e o próprio conceito de governo na economia" (VIDIGAL, 1986, p. 94).

No que diz respeito à ordem econômica o objetivo das propostas do empresariado foi a proteção à iniciativa privada, que, para Vidigal, era "manifestação da liberdade humana e condição da liberdade política" (idem, p. 95). A economia deveria organizar-se segundo as leis do mercado, cabendo à iniciativa privada a exploração das atividades econômicas. Para o então Presidente da FIESP, o Estado não poderia criar uma empresa que disputasse com a empresa privada. A ele caberia planejar o desenvolvimento econômico nacional e regional "por meio do entendimento entre o trabalho e o capital", proposta que ganhou progressivamente destaque no discurso empresarial a partir da segunda metade da década passada (ibidem).

A proposta do empresariado também abrangia os direitos dos trabalhadores, entre os quais o de greve. Esse direito deveria ser reconhecido, mas estariam proibidas as greves "nos serviços públicos e atividades essenciais; as greves políticas e de solidariedade; e as desencadeadas depois de assinados acordos ou convenções coletivas, após a homologação do laudo arbitral ou após decisão da Justiça do Trabalho proferida em dissídio coletivo, ressalvada a greve pelo não pagamento dos salários dentro dos prazos legais" (idem, p. 98).

Apesar de bastante detalhada, principalmente no que se refere à restrição do direito de greve, a proposta do empresário não menciona os demais temas que seriam debatidos na Constituinte. Temas da dimensão da reforma agrária ou do sistema de governo sequer são citados, caracterizando a ausência de um projeto abrangente do empresariado. A ausência de tal projeto não deixou de ser notada pelos empresários do PNBE e foi motivo de críticas em mais de uma oportunidade. Grajew, por exemplo, afirmou que "a discussão da dívida externa, que é básica, nem é levantada na FIESP" (GRAJEW, 1989).

Os estreitos limites da proposta para a Constituinte apresentada por Vidigal em nome do empresariado contrastam com a abrangência de inte- 
resses que aparece nas declarações de empresários vinculados ao PNBE. De fato, para essa entidade tratava-se de superar os limites impostos à ação empresarial pela estrutura tradicional de representação de interesses, extrapolando o nível dos interesses econômico-corporativos: "O PNBE realmente não teve uma idéia de se contrapor à FIESP no que diz respeito à ação corporativa da FIESP em prol da indústria e tal. As pessoas que compuseram o PNBE sentiam o espaço na FIESP muito limitado para outro tipo, para a ampliação e amplificação desta discussão de sociedade, do papel das pessoas. Essas questões estruturais todas que a gente tem que resolver. Então era muito na linha 'tá bom para mim, tudo bem' e a gente estava extremamente insatisfeito com isso. Achávamos que a gente tinha que participar do processo político efetivamente, além da dimensão corporativa" (ANÔNIMO, 23.jan.1996).

A crise orgânica, que caracterizava a situação vivida - articulação de uma crise econômica aguda com uma crise de representação - não escapou à percepção do empresariado. Emerson Kapaz analisou-a explicitamente em artigo publicado no jornal Gazeta Mercantil, no ano de 1989, justamente aquele que marcou os momentos mais agudos da crise. $\mathrm{O}$ artigo intitulou-se, emblematicamente, Uma crise de utopias se faz presente na América Latina. Nele, Kapaz articula três níveis da crise, o político, o social e o econômico: "No político, a crise se agudiza quer pela ineficácia das instituições políticas representativas frente à ação das elites com poder financeiro, quer pela internacionalização crescente das decisões políticas e pela falta de controle que a cidadania tem sobre as burocracias públicas. Contribuem, também, a configuração de um universo político carente de fundamento ético e a falta de uma 'cultura' democrática arraigada nas sociedades latinoamericanas. No social, a crescente fragmentação de identidades sócio-culturais, a falta de integração e comunicação entre movimentos sociais, a crescente exclusão social e política e o empobrecimento das grandes massas têm levado ao descontrole dos conflitos no seio das sociedades, impossibilitando respostas construtivas a tais conflitos. No econômico, o sistema de dominação sofre atualmente mudanças profundas, onde incidem de maneira substancial a mundialização da economia, o auge do capital financeiro, com seu enorme poder concentrador, e os múltiplos efeitos das sucessivas golfadas tecnológicas nos padrões de consumo" (KAPAZ, 1989).

E em um tom carbonário, Kapaz concluía, então, com a denúncia do “'garrote' da dívida externa", que, com a cumplicidade "dos governantes e das classes dominantes", impunha enormes sacrifícios aos países em desenvolvimento. É fácil saber quem são os governantes. Mas e as tais "classes dominantes"? Qual o lugar dos empresários nelas? Kapaz se auto-exclui, evidentemente, do universo dessas classes, dando a entender que apenas um pequeno grupo de empresários estaria incluído nelas. Grupo que é objeto, recorrentemente, da crítica do PNBE: "as grandes empreiteiras e bancos, os que desfrutam o poder em Brasília e algumas oligarquias regionais nos estados menos desenvolvidos", nas palavras de um coordenador do PNBE (HUMBERG, 1993); em outras ocasiões, a lista recebeu a adesão dos "monopólios e oligopólios" (CAPOBIANCO, 1997).

Os três níveis de desenvolvimento da crise desembocam, para Kapaz, em uma crise de utopias (crise orgânica?). Mas o que é, exatamente, essa crise? Ela é, fundamentalmente, a ausência de respostas alternativas ao autoritarismo, ao populismo e ao neoliberalismo que têm marcado a realidade latino-americana nas últimas décadas. A ausência de tais alternativas fez que as respostas a essa realidade assumissem a forma de "programas imediatistas ou se reduzem a reivindicações de recuperação dos "níveis históricos"” (KAPAZ, 1989).

Nas críticas aos "governantes" e às "classes dominantes", nas reclamações contra a ausência de um projeto alternativo, na afirmação de uma "crise de utopias", é possível ler uma profunda insatisfação com as respostas à crise que vinham sendo articuladas pela estrutura tradicional de representação do empresariado. A articulação dos níveis social, econômico e político da crise indica a vontade expressa de superar o caráter econômico-corporativo das propostas até então colocadas na mesa pelo empresariado e apresentar um novo programa de caráter hegemônico, global, portanto, como saída para a crise.

Coerente com essa vontade, o PNBE criou grupos de trabalho para analisar questões consideradas relevantes e apresentar respostas. Dentre esses grupos, destacavam-se, em 1993, os seguintes: Democracia e cidadania; Meio ambiente; Relações internacionais; Fórum Cidade de São Paulo; Fórum capital-trabalho; Articulação política; e 
Direito Econômico (PNBE, 1993c). Ao mesmo tempo, as ações do PNBE passaram a abranger temas até então ausentes da pauta das federações e confederações patronais, como as reformas política e do Estado, a ética empresarial, o contrato coletivo de trabalho e, principalmente, a constituição de um novo modelo de desenvolvimento nacional ${ }^{14}$.

Detenhamo-nos um pouco nesse último item. No início dos anos 1990, era voz corrente no meio empresarial, na imprensa especializada e na Academia, a noção de que o modelo de desenvolvimento baseado na substituição de importações e amparado na ação tutelar do Estado havia esgotado suas potencialidades. A crise brasileira era, assim, percebida, em grande parte, como crise de modelo. De fato, o discurso neoliberal tomava como ponto de partida, em nosso país, tal constatação para, a partir dela, deduzir de maneira abrupta a necessária retirada do Estado das atividades econômicas.

Não é diferente o ponto de referência que o PNBE e suas lideranças tomam para construir seu projeto, como deixa claro Emerson Kapaz em artigo publicado por ocasião de sua candidatura às eleições da FIESP (KAPAZ, 1992). Mas as semelhanças interrompem-se, pelo menos por enquanto, nesse ponto de partida. É o que evidencia a análise do documento programático Projeto nacional: o Brasil que queremos. Aprovado na $1^{\mathrm{a}}$ Convenção Nacional do PNBE, depois de uma série de reuniões e debates preparatórios, o Projeto nacional autodefine-se como um "anteprojeto de uma nação" (PNBE, 1994a).

É um anteprojeto ainda muito vago, é verdade, mas já é possível identificar nele uma vocação que supera os limites estreitos e imediatistas característicos da ação empresarial, ao mesmo tempo em que se distancia da proposta neoliberal. O Projeto nacional fez sua opção pela economia de mercado, mas, afastando do discurso então dominante, afirmou a necessária permanência do Estado com "tanto maior intensidade quanto mais precárias forem as condições sócio-econômicas que se verifiquem em razão de diversidades e peculiaridades regionais, setoriais e outras" (ibidem).

$\overline{14}$ Sobre a reforma política ver PNBE (1993a; 1994d); sobre a ética empresarial, PNBE (1994b); sobre o contrato coletivo, PNBE (1993b); para o Projeto nacional, ver PNBE (1994a; 1994c).
Para o PNBE, o Estado não se reduziria ao mínimo liberal. Ele deveria manter uma forte posição tanto na atividade econômica como na prestação de serviços. Assim, caberiam ao Estado, além das atividades inerentes ao seu "núcleo duro", como o controle monetário, as relações exteriores e a segurança nacional, funções outras, como "a universalidade da educação básica até o Segundo Grau. A assistência à infância, à velhice, aos deficientes, aos desvalidos e aos desempregados; a criação, a construção e a manutenção da infraestrutura e dos serviços básicos; combate às endemias; o estímulo à produção e ao desenvolvimento tecnológico" (ibidem).

A essa lista seria necessário acrescentar a garantia de "uma renda mínima a todos os cidadãos que não consigam, temporária ou definitivamente, auferir renda própria" (ibidem). Como podemos constatar, no centro da visão dessa associação empresarial, ou pelo menos da maioria dos seus associados, expressa através dos documentos da entidade, não está a suposta capacidade autoreguladora do mercado.

O distanciamento do PNBE do modelo neoliberal de Estado mínimo assumiu, por vezes, tons bastante fortes. No Fórum Nacional sobre Contrato Coletivo e Relações de Trabalho no Brasil, o representante do PNBE, Alberto Mac Dowell de Figueiredo, definiu da seguinte maneira a posição do PNBE: "Há dois modelos de Estado. O primeiro é o modelo idiota, do Estado liberal que não tem função, que não intervém onde tem que intervir. O segundo é o hipócrita, que não induz os atores sociais a amadurecerem porque os substitui" (MINISTÉRIO DO TRABALHO, 1994, p. 285).

Mas, além de ser uma nota dissonante em meio a um consenso neoliberal, o que a proposta do PNBE traz de inovador ao discurso empresarial é uma persistente afirmação da negociação e do entendimento nacional como chave para a saída da crise econômica e política que caracterizou a década de 1980 e parte da década de 1990. É aqui que o projeto da entidade adquire uma vocação global, hegemônica, propondo não só um processo de mobilização permanente da sociedade, como um alargamento dos interesses representados no Estado e a incorporação de demandas da classe trabalhadora. Tal projeto resume-se como uma "profunda transformação cultural e ética" (PNBE, 1994a).

A proposta do PNBE é, assim, uma proposta 
de mobilização nacional, que, ultrapassando o horizonte das relações entre empresários individuais e o Estado, propõe uma rearticulação das relações existentes entre a sociedade e o poder político. Cabe ressaltar que nessa rearticulação não caberia ao poder político o papel preponderante e sim às relações capital-trabalho. Sustentando essa visão está uma proposta de relação capital-trabalho muito distante daquela que caracterizou a FIESP na década de 1980 e uma crítica à estrutura corporativista tutelada pelo Estado ${ }^{15}$.

Em documentos da entidade, empresários e trabalhadores são apresentados como "os dois legítimos agentes e alvos do desenvolvimento da sociedade" (FIGUEIREDO, 1993). Constituindo um "sistema interdependente de soma zero", capital e trabalho deveriam estabelecer uma relação capaz de maximizar os ganhos para ambas as partes. Segundo um dos líderes do PNBE, em artigo publicado no jornal Pensamento empresarial, a "apropriação por qualquer dos agentes de parcela maior que a de sua competência, significa alterar a margem de contribuição, harmonia e equilíbrio do sistema num processo em cadeia que levará à ruptura" (idem).

O discurso do PNBE rejeita, entretanto, a afirmação, muito em voga, da parceria capital-trabalho: "trabalho e capital são co-responsáveis nos empreendimentos produtivos, embora tenham interesses conflitantes. Reconhecido o conflito de interesses, não se pode falar em parceria entre trabalho e capital, o que pressuporia objetivos comuns, o que não é claramente o caso" (PNBE, 1994b).

Para Figueiredo, a "negação do conflito impede que o jogo seja jogado, mas a única forma de se jogar este jogo com equilíbrio é reconhecer a legitimidade dos interesses das partes" (MINISTÉRIO DO TRABALHO, 1994, p. 37). O reconhecimento do conflito não implica, entretanto, para esses empresários, que a solução deste passa pela negação de uma das partes. Capital e trabalho podem convergir em um processo de negociação,

\footnotetext{
15 Eli Diniz mostrou o grande apego do empresariado à herança corporativo-autoritária. Esse apego manifestou-se tanto na intransigência com que esse empresariado enfrentou as greves metalúrgicas de meados da década passada com em suas propostas de limitação do direito de greve (DINIZ, 1985; 1997, p. 48-52).
}

no qual um acordo, que contente ambos, pode ser alcançado. Para o PNBE, "negociações sérias e maduras devem propor a convergência por troca entre os agentes" (PNBE, 1992b).

Embora admitido, o conflito entre capital e trabalho é esvaziado de significado ao ser apresentado unicamente como um conflito distributivo. A esfera da produção, e, portanto, a própria reprodução de relações sociais contraditórias, é descartada. Eliminada a base do conflito, ele pode, não só, facilmente ser admitido, como também incorporado à análise.

O ponto de partida desse esvaziamento é a afirmação de que capital e trabalho são parte de um sistema interdependente, um jogo de soma zero. Isso implica admitir o crescimento econômico capitalista e o lucro como pressupostos indispensáveis para o funcionamento do sistema, muito embora digam respeito a apenas um dos pólos da relação. Aqui, o pólo mais poderoso do conflito impede que a racionalidade pré-existente seja questionada, implicando que a ordem atual seja mantida e continuamente reafirmada e reconstruída. Demandas, estratégias e táticas incompatíveis com esses pressupostos devem ser descartadas de antemão pelos participantes do jogo sob pena de que todos percam.

É Figueiredo quem melhor expressa, dentro da entidade, esses condicionantes para o entendimento e a negociação. Respondendo a uma pergunta sobre os objetivos da relação entre capital e trabalho, por ele mesmo formulada no Fórum já mencionado, Figueiredo afirma: "Primeiro, que exista a atividade econômica, que representa um resultado positivo para o conjunto da sociedade. [...] O segundo aspecto da questão é que a atividade econômica pressupõe o lucro, a remuneração do capital. É o lucro que viabiliza, moderniza e perpetua a atividade da empresa" (MINISTÉRIO DO TRABALHO, 1994, p. 38).

Fiel à sua proposta, o PNBE defendeu, ao longo dos primeiros anos da década de 1990, toda e qualquer iniciativa que pudesse criar as condições para a institucionalização dessas negociações. Apoiou e foi peça chave do entendimento nacional promovido pelo governo Collor; defendeu a instalação das câmaras setoriais e a extensão de suas atribuições (MINDLIN, 1991); propôs a criação de um Fórum Permanente de União Nacional, durante o governo Itamar Franco (PNBE, 1992a), dentre várias iniciativas. 
Mas tal projeto, entretanto, nunca assumiu contornos muito definidos. Foi muito mais uma profissão de fé do que um programa. A vitória eleitoral do PSDB, nas eleições de 1994, representaria uma inflexão nessa trajetória do PNBE. Tendo importantes lideranças ocupando postos destacados nas administrações estaduais do partido do Presidente Fernando Henrique Cardoso, a entidade gradativamente foi alterando o foco de seu programa. A ênfase nas novas relações capital-trabalho e as propostas de entendimento nacional foram cedendo espaço à defesa das reformas liberalizantes.

Ironia da história, o projeto hegemônico ao qual o PNBE acabou aderindo não nasceu de uma revitalização das lideranças empresariais, nem espontaneamente da relação capital-trabalho. Nasceu, justamente, do Estado que a entidade tanto atacou.

Recebido para publicação em 23 de maio de 2001.

Alvaro Bianchi (abianchi@osite.com.br) é Mestre em Sociologia na Universidade Estadual de Campinas (UNICAMP) e Professor da Universidade Metodista de São Paulo (UMESP).

\section{REFERÊNCIAS BIBLIOGRÁFICAS}

ANTUNES, R. 1992. A rebeldia do trabalho. O confronto operário no ABC paulista - 19781979. Campinas : Unicamp.

1995. O novo sindicalismo no Brasil. Campinas : Pontes.

BIELCHOWSKY，R. 1991. Ideología y desarrollo. Brasil, 1930-1964. Revista de la Cepal, Santiago de Chile, n. 45, p. 155-177, dic.

CAPOBIANCO, E. R. 1997. Privatizações deveriam desconcentrar riqueza. Folha de São Paulo, 11.maio.1997.

CARDOSO, F. H. 1983. O papel dos empresários no processo de transição : o caso brasileiro. Dados, Rio de Janeiro, v. 26, n. 1, p. 9-27.

CODATO, A. N. 1997. Sistema estatal e política econômica no Brasil pós-64. São Paulo : Hucitec/ANPOCS.

COHN, G. 1985. Problemas da industrialização no século XX. In : MOTA, C. G. (org.). Brasil em perspectiva. São Paulo : Difel.

CRUZ, S. C. V. 1995. Empresariado e Estado na transição brasileira. Um estudo sobre a economia política do autoritarismo (19741977). Campinas : Unicamp.

1997a. 1977/1978. Os empresários e a reemergência da 'questão social'. In :

(org.). O presente como história. Economia e política no Brasil pós-64. Campinas : IFCH/ Unicamp. Coleção Trajetória, v. 3. 1997b. Fragmentos do novo? Brasil : empresariado e crise no limiar dos 90. In : . (org.). O presente como história. Economia e política no Brasil pós-64. Campinas : IFCH/ Unicamp. Coleção Trajetória, v. 3.

CUT. 1994. Indicadores Desep. São Paulo : Departamento de Estudos Sócio-Econômicos e Políticos/Central Única dos Trabalhadores.

DINIZ, E. 1978. Empresário, Estado e capitalismo no Brasil : 1930-1945. Rio de Janeiro : Paz e Terra.

1984. Empresariado e transição política no Brasil : problemas e perspectivas. - Textos para discussão IUPERJ, Rio de Janeiro, n. 22.

1985. O empresariado e o momento político : entre a nostalgia do passado e o temor do futuro. Cadernos de conjuntura, Rio de Janeiro, IUPERJ, n. 1.

1997. Crise, reforma do Estado e governabilidade. Rio de Janeiro : Fundação Getúlio Vargas.

DINIZ, E. \& BOSCHI, R. R. 1987. Empresários e Constituinte : continuidades e rupturas no modelo de desenvolvimento capitalista no Brasil. Cadernos de conjuntura, Rio de Janeiro, IUPERJ, n. 11.

1993. Brasil : Um novo empresariado? Balanço de tendências recentes. In : DINIZ, E. (org.). Empresários e modernização econômica. Brasil anos 90. Florianópolis : UFSC/Idacom. 
DREIFUSS, R. A. 1981. 1964 : a conquista do Estado. Ação política, poder e golpe de classe. Petrópolis : Vozes.

FAUSTO, B. 1970. A Revolução de 30. São Paulo : Brasiliense.

FIGUEIREDO, A. M. D. 1993. Balde furado e rabo de avestruz. Pensamento empresarial, São Paulo, n. 1, p. 8-9, abr.

. 1994. Tecnologia e emprego. Pensamento empresarial, São Paulo, n. 4, p. 16, mar.

FIORI, J. L. 1993. Para uma economia política do Estado brasileiro. Textos para discussão IESP, São Paulo, n. 11.

GAZETA MERCANTIL. 1998. Balanço anual 1998. N. 22. São Paulo : Gazeta Mercantil.

GRAJEW, O. 1989. Grajew aceita que trabalhador participe no lucro da empresa. Entrevista. Diário do Grande $A B C$, São Bernardo do Campo, 4.jun.

GRAMSCI, A. 1977. Quaderni del carcere. Turim : Giulio Einaudi.

GROS, D. B. 1993. Liberalismo, empresariado e ação política na Nova República. In : DINIZ, E. (org.). Empresários e modernização econômica. Brasil anos 90. Florianópolis : UFSC/Idacom.

HUMBERG, M. E. 1993. O Brasil corre o sério risco de deixar de existir. Pensamento empresarial, São Paulo, n. zero, abr.

IEDI. s/d. IEDI : 10 anos. São Paulo : Instituto de Estudos para o Desenvolvimento Industrial.

KAPAZ, E. 1989. Uma crise de utopias se faz presente na América Latina. Gazeta Mercantil, São Paulo, 03.jun.1989.

1992. A hora da verdade. Folha de São Paulo, 23.fev.1992.

. 1994. Entrevista. Folha de São Paulo, 04.abr.1994.

. 1996. Entrevista (concedida ao autor). São Paulo, 27.jun.

KINGSTON, P. R. 1998. Corporatism, Neoliberalism, and the Failed Revolt of Big Business in Brazil. Lessons from the Case of IEDI. Journal of Interamerican Studies \& World Affairs, Miami, v. 40, n. 4, p. 73-93,
Winter.

LEOPOLDI, M. A. P. 2000. Política e interesses na industrialização brasileira. As associações industriais, a política econômica e o Estado. Rio de Janeiro : Paz e Terra.

MELLO, J. M. C.\& BELLUZZO, L. G. M. 1977. Reflexões sobre a crise atual. Escrita-Ensaio, São Paulo, n. 2.

MINDLIN, S. 1991. Não basta ser empresário, diz Mindlin. Entrevista. O Estado de São Paulo, 11.ago.1991.

MINISTÉRIO DO TRABALHO. 1994. Fórum nacional sobre contrato coletivo e relações de trabalho no Brasil. Brasília : Ministério do Trabalho.

MOTTA, F. 1979. Empresários e hegemonia política. São Paulo : Brasiliense.

PAYNE, L. A. 1994. Brazilian Industrialists and Democratic Change. Baltimore : The Johns Hopkins University.

PEREIRA, L. C. B. 1978. O colapso de uma aliança de classes. São Paulo : Brasiliense.

PNBE. s/d. PNBE. A nova consciência do empresariado brasileiro. São Paulo : Pensamento Nacional das Bases Empresariais.

. 1992a. Carta ao Presidente da República Federativa do Brasil Itamar Franco. 02.out.

. 1992b. Modernização das relações entre trabalho e capital. Proposta detalhada. São Paulo : Pensamento Nacional das Bases Empresariais.

. 1993a. Reformas políticas para o Brasil. São Paulo : Pensamento Nacional das Bases Empresariais.

1993b. Adeus CLT. O contrato coletivo entra em cena. Pensamento empresarial, São Paulo, n. 1, p. 10-11, jul.

. 1993c. O país do PNBE. Pensamento empresarial, São Paulo, n. 1, p. 2, jul.

. 1994a. Projeto nacional. O Brasil que queremos. São Paulo : PINI.

1994b. Ética nos negócios : qual é a fronteira da transgressão. Pensamento empresarial, São Paulo, n. 3, p. 4-5, mar.

.1994c. O país que queremos. Com qualida- 
de de vida. Pensamento empresarial, São Paulo, n. 6, p. 12-14, set.

1994d. Os novos eleitos e a velha burocracia. Pensamento empresarial, São Paulo, $\mathrm{n}$. 8, p. 6-9, dez.

1998. Livro do ano 97/98. Dez anos de realizações em favor da cidadania. São Paulo : Grupo de trabalho Comunicação e marketing/ J.J. Carol.

ROSSI, C. 1994. Viva a ineficiência. Folha de São Paulo, 14.ago.

SCHNEIDER，B. R. 1997-1998. Organized Business Politics in Democratic Brazil. Journal of Interamerican Studies \& World Affairs, Miami, v. 39, n. 4, p. 95-125, Winter.
SEMLER, R. 1996. O estado de coma da FIESP. Folha de São Paulo, 21.jun.

SOLA, L. 1998. Idéias econômicas, decisões : políticas : desenvolvimento, estabilidade e populismo. São Paulo : Edusp/FAPESP.

VIDIGAL, L. E. B. 1986. O empresário e a constituinte. Palestra proferida na Federação das Indústrias do Estado de Minas Gerais. Belo Horizonte, 08.nov.1985. Indústria e desenvolvimento, n. 20 , v. 9, p. 94-99.

WEYLAND, K. 1998. The Fragmentation of Business in Brazil. In : DURAND, F. \& SILVA, E. (orgs.). Organized Business, Economic Change, Democracy in Latin American. Miami : North South Center Press.

\section{OUTRAS FONTES}

Entrevistas com empresários, realizadas sob condição de anonimato, em 23.jan.1996, 26.jun.1996 e 27.jun.1996.

"Vou aumentar os impostos". O Estado de São Paulo, 06.out.1987.

Até onde a Natura consegue ir? Exame, São Paulo, 10.set.1997, p. 118.

Bresser diz a empresários que impostos devem subir. Jornal do Brasil, Rio de Janeiro, 06.out.1987.

Críticas, sugestões, risos... Diário do Comércio e da Indústria, São Paulo, 06.out.1987.

Efeitos da negociação. Veja, São Paulo, 20.set.1978.

Eleição na FIESP mexe com país. Jornal do Brasil, Rio de Janeiro, 03.fev.1992.

Empresário ataca falta de política industrial. Folha de São Paulo, 10.jun.1996.

Entidade quer mais investimento interno. Folha de São Paulo, 11.ago.1997.
Ministro recebe apoio de empresários no Anhembi. O Globo, Rio de Janeiro, 06.out.1987.

O chato que funciona. Veja, São Paulo, 05.mar.1997.

O documento dos oito. Veja, São Paulo, 05.jun.1978.

O significado político do encontro com o PNBE. Gazeta Mercantil, São Paulo, 06.out.1987.

Outras bases. Folha de São Paulo, 30.jun.1996.

PNBE assusta. $O$ Globo, Rio de Janeiro, 06.out.1987.

PNBE fora da direção da FIESP. Diário do Comércio e da Indústria, São Paulo, 03.01.1988.

Um tom abaixo. Veja, São Paulo, 27.set.1978.

Pensamento empresarial. 1993. São Paulo, n. 3, dez. 1993

Pensamento empresarial. 1994. São Paulo, n. 4, mar. 1994. 